du miroir et pour sa construction, est donnée par un développement en série selon les puissances de la hauteur d'incidence du rayon.

M. F. Link signale l'utilité que présenterait un recueil de données numériques relatives aux propriétés des liquides susceptibles d'être employés comme milieux dispersifs. Il veut bien se charger de préparer un tel travail, ce dont la Commission le remercie vivement.

M. Henri Chrétien dépose sur le bureau, de la part du Capitaine Hellweg, de l'Observatoire Naval de Washington, quelques photographies du télescope RitcheyChrétien d'un mètre d'ouverture, qui vient d'être mis en service, ainsi que des photographies stellaires qui montrent l'efficacité du nouvel instrument.

M. A. Couder propose à la Commission, qui l'adopte à l'unanimité des membres présents, le projet de résolution suivant:

"Les auteurs d'instruments destinés à des recherches astronomiques, doués de propriétés optiques nouvelles, sont priés de donner toujours l'indication complète des données de construction, sous une forme qui permette un examen critique et éventuellement la reproduction: indices et dispersion des matières employées, courbures des surfaces, épaisseurs et distance des lentilles et, si possible, la description des aberrations résiduelles et des propriétés photométriques."

\title{
COMMISSION Io (SUNSPOTS AND CHARACTER FIGURES)
}

\author{
President: Prof. W. Brunner. \\ SECRETARY: Rev. LuIS RodÉs, S.J.
}

The Commission met on Thursday, August 4. The suggestion made by the President and by d'Azambuja to change the title of the Bulletin was first considered. After a short discussion on the most appropriate terms for this, a resolution was passed adopting Quarterly Bulletin on Solar Activity (Bulletin Trimestriel relatif à l'Activité Solaire). The President then referred to the advisability of continuing the publication of the character figures, separately for the whole disk and for the central zone, and proposed, seconded by Abettiand d'Azambuja, to omit in future the former and to retain only the latter, as long as they might be considered of some utility for statistical purposes. After a short exchange of views between several members (Abetti, d'Azambuja, Stratton, Royds, Rodés) who favoured the President's suggestion, a resolution was passed adopting it.

The President asked that the Commission support the Zurich Observatory when organizing a scheme of taking direct photographs of the Sun at short intervals, studying the manner of development of spots and spot groups. Attention was drawn to the fact that, since the character figures for the central zone are to be omitted in the Bulletin, there will be space for other data, which might be more useful. The President suggested publishing a time-diagram showing for each day the hours on which the Sun was under observation by the various spectrohelioscopes; he referred also to a suggestion of S. B. Nicholson to introduce daily character figures for bright chromospheric eruptions based on the number and intensity, and on the number of hours the Sun was observed per day. D'Azambuja finds that while some observers give the exact time during which they were actually observing the Sun, others merely give a total period of observation during which there might have been interruptions; he thought that gaps in the observations exceeding five minutes should 
be stated. Stratton expressed the opinion, confirmed by several members, that no daily character figure for bright chromospheric eruptions should as yet be adopted until the suggestion was tried out by individual observers. No definite decision was therefore taken on either of these two matters, and as these questions also concern Commission II it was thought better to continue the discussion in a meeting of that Commission. It was agreed to leave the whole matter in the hands of the respective Presidents of Commissions ro and II, who would inform the members by a circular letter in due course.

\title{
COMMISSION II (CHROMOSPHERIC PHENOMENA)
}

\author{
President: Dr L. D'Azambuja. \\ SeCRETARY: Mr H. W. Newton.
}

Réunion du vendredi, 5 août, $\grave{d} 9^{\mathrm{h}} 30^{\mathrm{m}}$. Le Président rappelle la perte cruelle que la Commission a faite en la personne de George Ellery Hale, décédé le 21 février r938, à l'âge de 70 ans. Il annonce avec regret la mort accidentelle, survenue quelques jours à peine avant le Congrès, au cours d'une ascension dans les Alpes, d'un autre membre de la Commission, Emile Merlin.

Il met ensuite en discussion le rapport provisoire de la Commission. M. Moss demande à modifier quelque peu le texte relatif à l'activité de l'Observatoire de Cambridge. La Commission acquiesce au désir exprimé par M. Moss; le rapport provisoire est alors adopté.

Deux demandes de subventions ont été soumises à la Commission: l'une, de M. le Prof. Abetti, pour continuer la publication des Immagini spettroscopiche del bordo solare; l'autre, de M. le Prof. E. Esclangon, pour poursuivre celle des Cartes synoptiques de la chromosphère établies à Meudon. Ces deux demandes sont approuvées sans discussion par la Commission.

L'ordre du jour appelle l'examen de la possibilité de développer l'étude des mouvements dans les protubérances et d'organiser une coopération internationale pour réaliser des films de ces objets sur un intervalle de temps plus grand que la durée maxima d'une observation continue dans un seul établissement.

Le Président expose que, depuis le dernier Congrès, la cinématographie des protubérances a fait d'importants progrès et présente, à n'en pas douter, de très grands avantages sur les méthodes antérieurement employées pour étudier les mouvements de ces formations. Le procédé ne s'applique, il est vrai, qu'aux mouvements perpendiculaires au rayon visuel, mais on peut concevoir aisément un dispositif dans lequel un spectro-enregistreur des vitesses radiales fonctionnerait simultanément avec l'appareil cinématographique, pour compléter les données fournies par celui-ci. D'autre part, les films déjà réalisés ont souvent des lacunes, soit par suite de passages de nuages pendant la prise de vues, soit parce que la durée du phénomène enregistré dépasse le temps dont un observateur isolé dispose au cours d'une seule journée. Il serait donc hautement désirable d'organiser une coopération grâce à laquelle des films d'une même protubérance, obtenus sur un modèle uniforme par diverses stations convenablement distribuées en longitude, seraient réunis par un observatoire centralisateur qui en composerait un film unique, présentant le minimum de lacunes.

Un échange de vues a lieu au cours duquel MM. d'Azambuja, Lyot, Abetti, 